\title{
The Fourth Industrial Revolution and the disruptive technologies: implications in work relations
}

\author{
Leiraud Hilkner de Souza', Antonio Carlos Massabni² \\ *Corresponding author: E-mail address: leiraud@gmail.com
}

Abstract: This research covers an analysis of the essential aspects involving the Fourth Industrial Revolution, disruptive technologies and their consequences on work relations. Using literature reviews and analyzing cases of companies that failed and others that remodeled themselves to survive the yearnings of the technological age it was possible to obtain important results. The research was conducted in three parts: (i) historical contextualization guiding the reader on the main aspects and peculiarities of the Fourth Industrial Revolution; (ii) definition, application and some examples of disruptive technologies; (iii) confirmation of the impact of these technologies on work relations. The methods used were: hermeneutics, privileging theoretical studies and analysis of documents and texts and the deductive method, starting from existing laws and theories for the development of a logical reasoning to explain the central problem. Negative impacts of mass unemployment due to the replacement of human labor by highly technological machines cannot be estimated. These machines are part of what has been called disruptive technology, i.e., an innovative product that destabilizes competition, overcoming it in such a way that it promotes the rupture of existing models, ruining them. Professionals will be called to fill new jobs, with skills and competencies for Industry 4.0 , whose interaction between man and machine will be essential. Use of big data in quality control, robots, fully automated vehicles, 3D printers in production lines, among other activities are examples of work demands.

Keywords: Fourth Industrial Revolution; Disruptive technologies; Work relationships.

\section{Introduction}

The technological revolution and the new business dynamics imposed by capitalism, with a view to free trade and the Fourth Industrial Revolution have affected work relations, business models have been created, labor rights have been mitigated, but the great concern is about jobs and the future of workers, because the impacts will be even greater as there will be elimination of traditional jobs and, consequently, significant increase in unemployment rates.

It is well known that the Fourth Industrial Revolution is happening and, allied to it, paradigm shifts and the implementation of the so-called disruptive technologies, directly affecting the productive process, the routine of companies, promoting such a restructuring that it is already being talked about replacing human work with machines in high percentages and, in many activities, the replacement will be so accentuated that it will cause the extinction of professions, leaving a large number of unemployed people.

There is no doubt that the technological revolution and the new entrepreneurial dynamic imposed by capitalism towards free trade and the Fourth Industrial Revolution have affected work relations. However, there are positive aspects to be considered, such as greater convenience of society, innovation with research, scientific and technological development never seen before, but there are also extremely harmful points to be analyzed, involving government, human conduct (interpersonal and practice of offenses), environmental degradation, and increasing inequality and poverty. In short, revolution is synonymous of transformation and it is not always for good, so it is necessary to discuss the subject of this work, with a view to overcoming the original barriers of Revolution 4.0, considering what humanity intends to reach, what values should be protected and what measures should be taken to minimize the detrimental impacts on human development itself and the maintenance of our own essence: humanity.

\section{Objectives}

In general terms, the objectives are to analyze the relevant aspects of the Fourth Industrial Revolution, defining disruptive technologies, verifying the impacts caused on work relations by technology, robotics and automation and studying some work modalities based on technological advances. In this way, this work demonstrates the relevant aspects of the Fourth Industrial Revolution and the impacts caused on work relations by technology, robotics and automation.

But what is the repercussion of all this? How to prepare for this scenario? What is the role of the governments? These and other questions were addressed in this work, envisioning the adoption of means and public policies which minimize the negative and harmful impacts on human development.

\section{Methodology}

It is intended, by a literature review, to analyze doctrinal studies, articles, current laws and other materials that may be necessary for the pursuit of the objectives outlined in this research. The methods used are: hermeneutics, privileging theoretical studies and analysis of documents and texts and the deductive method, starting from existing laws and theories for the development of a logical reasoning to explain the central problem.

\section{Historical Contextualization}

The Fourth Industrial Revolution began at the end of the 20th century, based on the digital revolution, which is characterized for uninterrupted access to the Internet through mobile devices (cell phones and notebooks, for example), smaller size, greater processing capacity and mass production of hardware that has become cheaper and for artificial intelligence and automatic learning. The so-called Revolution 4.0 is much more complex and goes far beyond real-time connected intelligent sys-

${ }^{1}$ PhD student of the Graduate Program in Biotechnology, Regenerative Medicine and Medicinal Chemistry of University of Araraquara (Uniara).

2 Professor of the Graduate Program in Biotechnology, Regenerative Medicine and Medicinal Chemistry of University of Araraquara (Uniara). 
The Fourth Industrial Revolution and the...

tems and machines. Other areas, such as genetic sequencing, nanotechnology, renewable energies and quantum computing are also relevant.

Drawing a historical overview of all the industrial revolutions, as to their main characteristics and the time of transition from one to another, it is possible to state that the Fourth Revolution develops much faster, being considered by researchers and historians the largest revolution in industry since the First Industrial Revolution, occurred in the 18th century (Table 1).

\begin{tabular}{|c|c|c|c|c|}
\hline \multicolumn{5}{|c|}{ INDUSTRIAL REVOLUTIONS } \\
\hline & Period & Milestone & Main features & Main impacts \\
\hline 1 st & $\begin{array}{l}\text { Half of the } \\
18 \text { th } \\
\text { century - } \\
\text { from } 1760 \\
\text { to } 1860 \\
\text { began in } \\
\text { England. }\end{array}$ & $\begin{array}{l}\text { Invention of the } \\
\text { steam engine } \\
\text { and its } \\
\text { application in } \\
\text { textile } \\
\text { production; } \\
\text { Invention of } \\
\text { new steam } \\
\text { transport } \\
\text { systems, such } \\
\text { as locomotives. }\end{array}$ & $\begin{array}{c}\text { Coal mining as a new source of } \\
\text { energy; } \\
\text { Increasing and accelerating } \\
\text { production (large-scale production } \\
\text { mode); } \\
\text { Replacement of human labor. }\end{array}$ & $\begin{array}{c}\text { Replacement of human labor } \\
\text { (unemployment) and cheapening of } \\
\text { the labor force; } \\
\text { Rural exodus, growth of cities; } \\
\text { Endemic diseases; } \\
\text { Increase in production, in the } \\
\text { number of factories and in } \\
\text { competitiveness. }\end{array}$ \\
\hline 2nd & $\begin{array}{l}\text { Half of the } \\
19 \text { th } \\
\text { century- } \\
\text { from } 1860 \\
\text { to } 1960 .\end{array}$ & $\begin{array}{c}\text { Electricity and } \\
\text { the discovery of } \\
\text { oil as a source } \\
\text { of energy. }\end{array}$ & $\begin{array}{c}\text { Faster technological development; } \\
\text { Development of the chemical and } \\
\text { steel industries; } \\
\text { Industrial organization and } \\
\text { production models developed by } \\
\text { Frederick Taylor and Henry Ford; } \\
\text { Innovations: automotive, } \\
\text { telephone, radio and aircraft. }\end{array}$ & $\begin{array}{c}\text { Faster progress in the industry than } \\
\text { in agriculture; machine-made and } \\
\text { factory-mounted products; } \\
\text { Capital-controlled industrial } \\
\text { production; } \\
\text { Workers' movements for rights } \\
\text { (wages, reduced hours, health and } \\
\text { safety at work); } \\
\text { Verticalization of labor relations } \\
\text { (separation: intellectual and manual } \\
\text { labor); } \\
\text { The US was elected as the world's } \\
\text { main industrial center with the } \\
\text { emergence of Ford's revolutionary } \\
\text { production techniques. }\end{array}$ \\
\hline 3rd & $\begin{array}{l}\text { After the } \\
\text { Second } \\
\text { World War } \\
\text { - from } \\
1960 \text { to } \\
1990 \text { (20th } \\
\text { Century). }\end{array}$ & $\begin{array}{l}\text { Nuclear power } \\
\text { discovery. }\end{array}$ & $\begin{array}{c}\text { Emergence of electronic } \\
\text { equipment, telecommunications } \\
\text { and computers; } \\
\text { Space exploration (man reached } \\
\text { the moon); } \\
\text { Research in the field of } \\
\text { Biotechnology; } \\
\text { Invention of robots and automata; } \\
\text { Toyotism production mode, } \\
\text { created by Taiichi Ohno, a Toyota } \\
\text { employee. }\end{array}$ & $\begin{array}{l}\text { The changes outweigh the } \\
\text { industrial transformations. In this } \\
\text { phase, technological processes are } \\
\text { born from the interaction between } \\
\text { science and production, also known } \\
\text { as the techno-scientific revolution. }\end{array}$ \\
\hline 4th & $\begin{array}{l}\text { Late } 20 \text { th } \\
\text { century - } \\
\text { from } 1990 \\
\text { to the } \\
\text { present } \\
\text { day. }\end{array}$ & $\begin{array}{l}\text { Interconnection } \\
\text { of all stages of } \\
\text { production, } \\
\text { based on the } \\
\text { scanning of } \\
\text { information - } \\
\text { storage and } \\
\text { use of data. }\end{array}$ & $\begin{array}{l}\text { Artificial intelligence: machines } \\
\text { "learn" and perform activities } \\
\text { without human interference; } \\
\text { High data and information storage } \\
\text { capacity; } \\
\text { Power generation with lower } \\
\text { pollutant index; } \\
\text { Use of nanotechnology for } \\
\text { scientific innovation, creation of } \\
\text { materials and improvements in } \\
\text { health - widely used in information } \\
\text { technology, communication, } \\
\text { medicine and pharmaceuticals. }\end{array}$ & $\begin{array}{l}\text { This phase has barely begun and } \\
\text { the impacts can be seen in all } \\
\text { sectors of society (economic, } \\
\text { political, social and environmental). } \\
\text { Cutting-edge technology, the } \\
\text { emergence of virtual currencies } \\
\text { (bitcoin), 3D printing, big data (data } \\
\text { set on the internet motivated by the } \\
\text { increased speed of the internet), } \\
\text { robotics, augmented reality, } \\
\text { artificial intelligence and } \\
\text { nanotechnology are examples of } \\
\text { this revolutionary historical phase. }\end{array}$ \\
\hline
\end{tabular}

Table 1 - Relevant aspects of Industrial Revolutions. Source: Adapted from Penprase, $2018 .{ }^{2}$ 


\section{H. Souza, A. C. Massabni}

As can be seen, technology and digitalization have only started to influence the production system in general. The evolution and achievements of the Fourth Industrial Revolution continue at a surprising rate.

According to Anderson, ${ }^{3}$ the last decade has been about discovering new ways to create, invent and collaborate on the internet. The next decade will aim to apply that learning to the real world. Disruptive technologies have contributed to this result. Briefly, disruptive technology is an innovative product or service (creates a new market) that destabilizes the previously dominant competition. Disruptive, because it comes from a rupture, these products or services transform the market in such a way that they promote a true rupture, the ruin of the previously existing models. ${ }^{4}$ The services provided by Uber, Apple, Netflix and Google are examples that revolutionized ways of locomotion, listening to music, watching movies and searching for information on the internet, respectively.

Technologies considered disruptive, for example artificial intelligence, natural language processing and computer vision, are turning from revolutionary ideas into essential business tools, and this is just the beginning. ${ }^{5}$

In addition to the positive impacts from the use of disruptive technologies, there will be extremely negative impacts, harmful to society and the state itself in terms of work relations, which cannot be prevented, because the global economic scenario denotes high competitiveness and whoever goesahead will lead the ranking of the most powerful companies.

Schwab states that the Fourth Industrial Revolution will have a tremendous impact on the world economy, will be vast and multifaceted

and will not be able to separate one effect from the other. ${ }^{1}$

Therefore, the analysis of the impacts on labor relations from the disruptive technologies in the Fourth Industrial Revolution is of paramount importance and general interest, mainly with the intention of creating mechanisms for governments to fulfill its role in the protection of fundamental social rights, guaranteeing the constitutional principles and precepts, among them the right to work and a decent life.

\section{ogies \\ Definition, application and examples of disruptive technol-}

The name "disruptive technology" is strange at first, but it is responsible for breaking current paradigms, for the serious impacts on the economy, politics, economy and society - people already use disruptive technologies in daily life, companies are investing more and more in the search for the "new that implicate", that is, the disruptive technologies are a reality of this century and make history in the Fourth Industrial Revolution; there is no stopping them; studies, development of strategies and public policies to remedy and prevent their negative impacts are essential.

The word "disruptive" means something that causes or can cause disruption; ultimately it interrupts the regular follow-up of a process; it has the ability to break or alter. ${ }^{6}$ Therefore, disruptive technology is that which breaks standards, models or technologies established in the market. Instead of being an evolution of a product or service, it is a disruption. ${ }^{7}$ Table 2 shows the main disruptive technologies.

\begin{tabular}{|l|l|}
\hline \multicolumn{2}{|c|}{ DISRUPTIVE TECHNOLOGIES } \\
\hline Analytics & $\begin{array}{l}\text { Allows to creation of relationships between variables and business } \\
\text { data directing the entrepreneur (or managers) to make decisions in } \\
\text { sales, logistics and finance. }\end{array}$ \\
\hline Cryptocurrencies and blockchain & $\begin{array}{l}\text { Cryptocurrencies are currencies and digital transactions. } \\
\text { Blockchain is a decentralized and secure technology. It would bea } \\
\text { kind of "accounting book" (it registers transactions, being mirrored } \\
\text { by numerous PCS, for auditing by anyone, but cannot be copied or } \\
\text { altered by them). }\end{array}$ \\
\hline Shared economy & $\begin{array}{l}\text { Especially for travel and journeys through private car sharing - } \\
\text { reduction in the sale of goods (such as cars and houses), it will not } \\
\text { be necessary to "have" to "use". }\end{array}$ \\
\hline 3D printing or rapid prototyping & $\begin{array}{l}\text { Additive manufacturing technology from a three-dimensional } \\
\text { model, created by printing on successive layers of material; used } \\
\text { for the construction of buildings, consumer products such as } \\
\text { household appliances, footwear and human organs. }\end{array}$ \\
\hline Artificial intelligence & $\begin{array}{l}\text { Robotic devices, some with the ability to learn from their } \\
\text { experiences. } \\
\text { Connection of machines via internet for data sharing. }\end{array}$ \\
\hline Internet of things (IoT) & $\begin{array}{l}\text { Computational interface techniques, there are three-dimensional } \\
\text { interactive technologies (3D) that allow simulating product } \\
\text { characteristics, perform training of people, application in games } \\
\text { and use in e-commerce. }\end{array}$ \\
\hline Virtual and augmented reality &
\end{tabular}

Table 2 - Main disruptive technologies: Industry 4.0. Source: Adapted from Schwab․ 
Technological innovations have brought about major and relevant changes around the world, but that doesn't stop there. It is estimated that, in the next 20 years, the technology will be hundreds of thousands of times greater compared to today. ${ }^{8}$

For Schwab, technology and digitalization will revolutionize everything. To try to explain why current disruptions and innovations are so significant, Schwartz states that the speed of innovation has been faster than ever in terms of development and disruption. The existing disruptors such as Airbnb, Uber, and Alibaba, which are now benchmarks for companies in their industries, were relatively unknown a few years ago. The iPhone was launched in 2007 alone, and by 2015 there were already about 2 billion devices. ${ }^{6}$ In 2010, Google announced its first fully autonomous car, these vehicles will become a common reality on the streets.

The advancement of technology, the form and speed in which it has presented itself in recent times and the advances observed since the twentieth century are immense and extremely rapid compared to previous centuries. Technology is evolving faster than human capacity. ${ }^{9}$ Current mobile phones are more "powerful" than the NASA computer that took Apollo 11 to the moon on July 16, 1969. ${ }^{8}$

Today's smartphones are compact, lightweight mobile phones with extremely powerful processors, high data storage capacity (up to 256 $\mathrm{GB})$, extensible by attaching memory cards, high-resolution cameras, the possibility of recording videos in $4 \mathrm{~K}$, in short, a multitude of possibilities and functions that can be carried in pockets. Today's mobile phones are more "powerful" than the NASA computer that took Apollo 11 to the moon on July 16, 1969 (Figs. 1, 2 and 3)..$^{10-14}$

Companies that do not project and invest in technology will be doomed to failure and, of course, will close their doors. Like Kodak, a large company, consolidated in the photographic market in the 2000s. In the 1970s, Kodak held $80 \%$ of the market for cameras and $90 \%$ of photographic films. In that same decade, the company invented the digital camera, but "turned off" the technology by assuming that this new product would hurt its film sales. In 2002, the cameras with film lost space for the digital ones, the photographic market changed substantially, with a decline in the development of printed photographs, which became files able to be homemade printed by their users from the connection in USB cables in computers and, later, sent by signal, Bluetooth or the internet. ${ }^{15}$

In 2008, Kodak's largest share of revenues came from patent licensing rather than from the sale of its products and services. In January 2012, the company went into bankruptcy and participated in the government's program to protect companies for financial recovery. Apple, Google and other brands were major competitors, which led to several Kodak patents. It is reported that Kodak currently works in the business-oriented printing market and also in the packaging market, besides keeping contracts with movie studios to supply films. In 2016, the company tried to launch a smartphone called Ektra, relaunched a Super 8 camera and an action cam called PixPro, but did not have good reception in the market. ${ }^{15}$

With the Fourth Industrial Revolution, even digital camera manufacturers faced problems and fired many employees. Smartphones have increasingly technological cameras, some with up to three cameras, bringing convenience and high technology to users.

Another example is Atari, a Silicon Valley company that weakened in the 1980s, and even had to bury thousands of unsold videogames and take the loss. When the market recovered, other more innovative companies had taken the lead, such as Nintendo. Atari went bankrupt and was sold in 2008 with the intention of keeping the valuable brand alive. ${ }^{16}$

These examples reflect on the society and economic landscape of countries, especially those that do not project themselves and prepare to face the impacts and possible losses. How many unemployed people will be launched inday to meet the demands of this new, dynamic and demanding reality of full-time connected consumers, thirsty for the latest technological releases. The answers should be sought from a careful analysis of each sector of the economy, to practice actions to minimize the losses and how to remedy them.
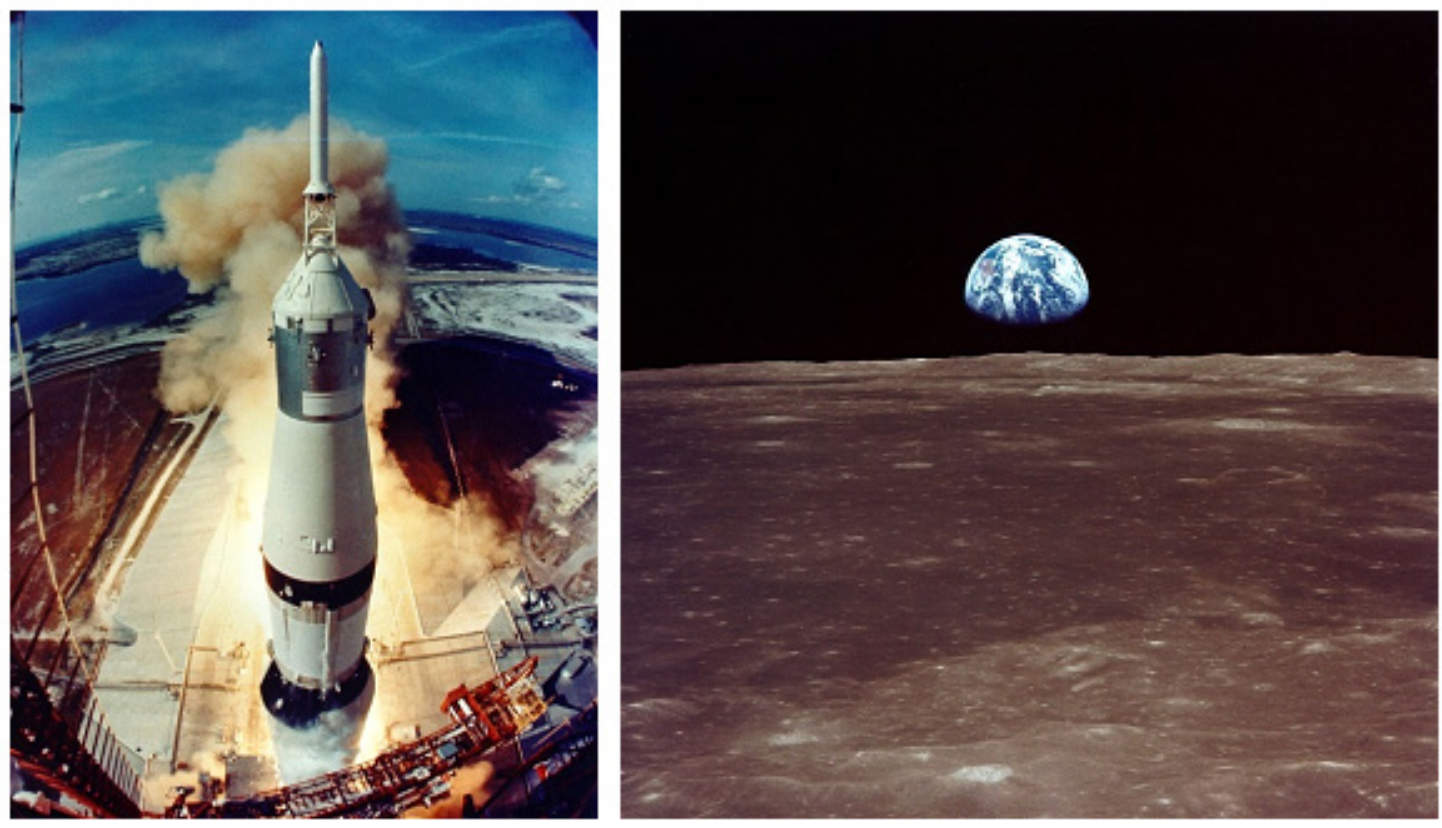

Left: Saturn V rocket takes off on the morning of July 20, 1969. Right: "Earthrise" seen from the moon.

Figure 1 - Man's arrival on the moon in 1969. Source: NASA. The use of these images is regulated under the Creative Commons license ${ }^{10,11}$ 


\section{H. Souza, A. C. Massabni}
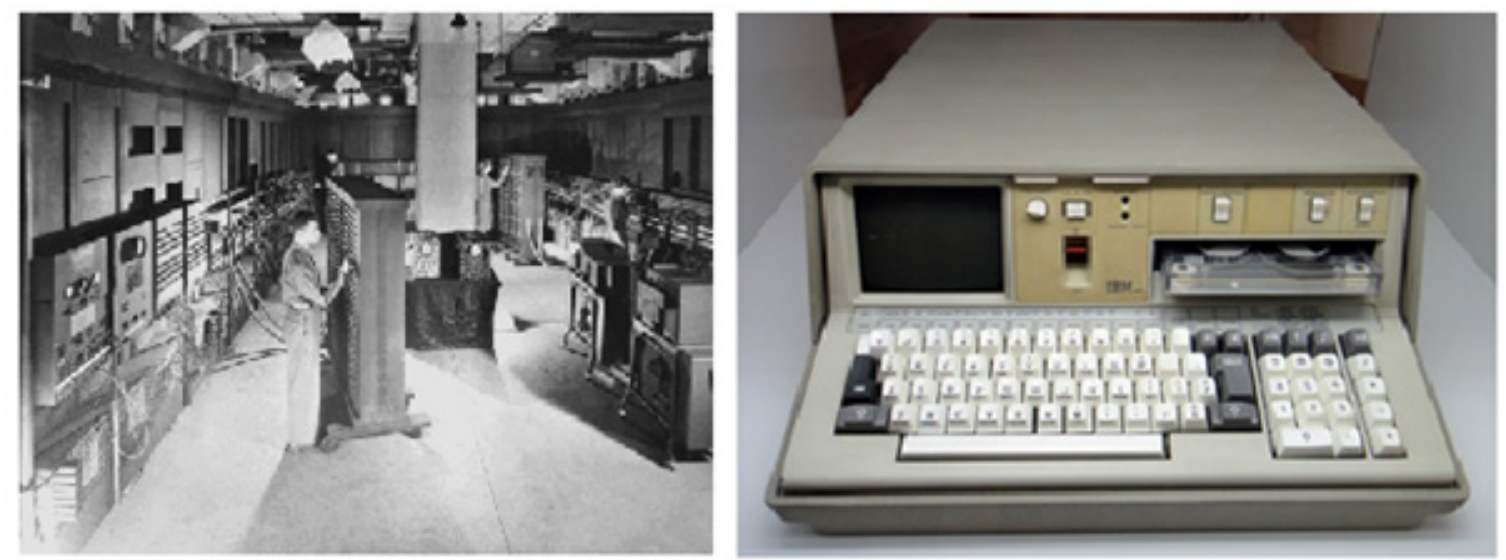

Left: ENIAC (Electrical Numerical Integrator and Calculator), the world's first computer (1946). (This image is a work of the U.S. federal government and is in the public domain).12 Right: IBM 5100, one of the first personal computers to be commercialized (1975) (the use of these images is regulated under the Creative Commons license). ${ }^{13}$

Figure 2 - The world's first computers.

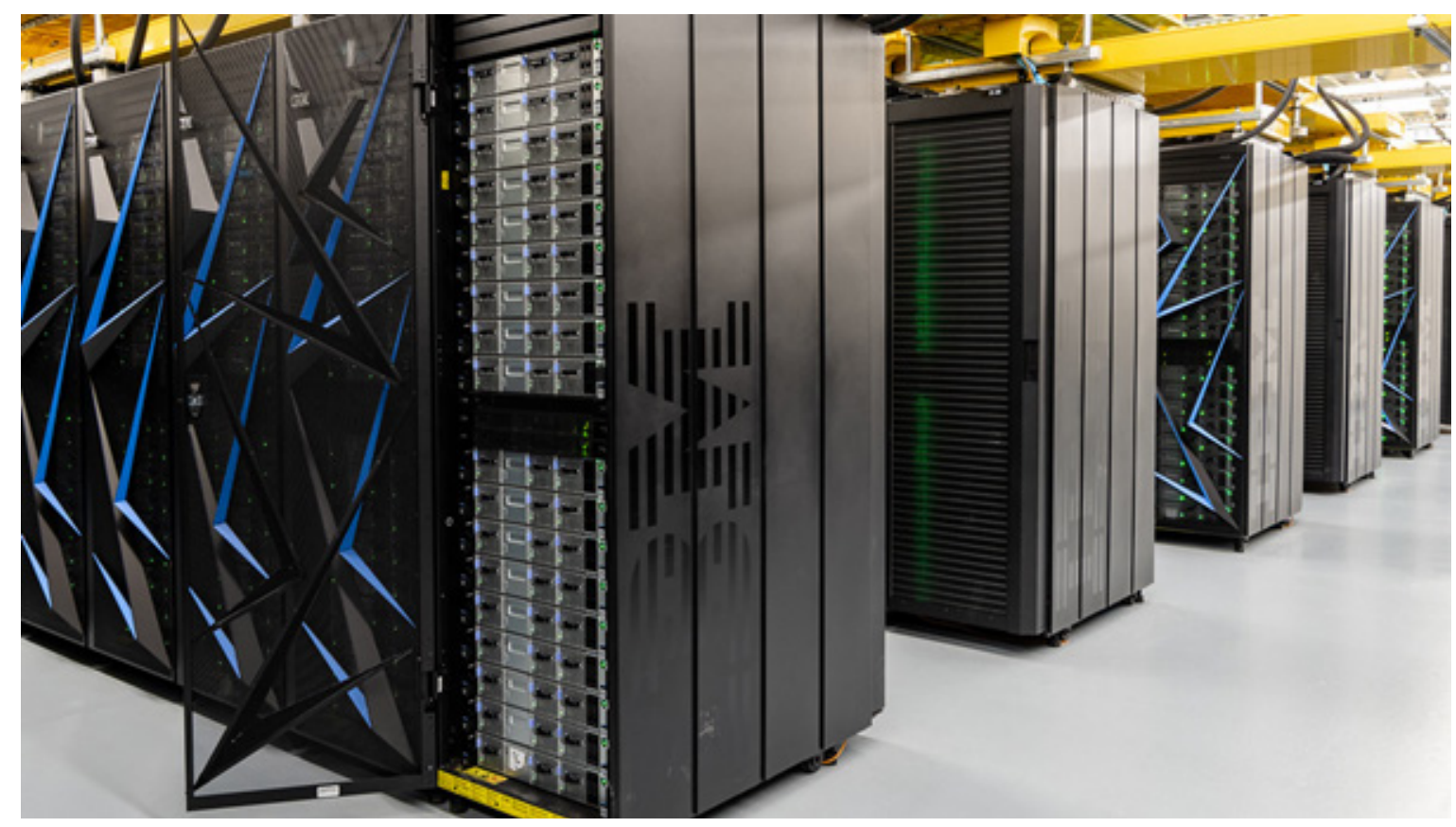

Built by IBM and Nvidia for the U.S. Department of Energy's Oak Ridge National Laboratory, the Summit is a 200 petaflops machine (can do 20 quadrillion calculations per second). (the use of these images is regulated under the Creative Commons license).9,14

Figure 3 - Summit: world's most powerful computer. 


\section{Impacts of disruptive technologies on work relations}

Industry 4.0 will promote even more impacts, especially in work relations regarding employability and the need to improve skills for handling new technologies based on the qualification of the professional.

Tessarini Junior and Saltorato, ${ }^{17}$ after studying the impacts of Industry 4.0 on the organization of work, categorizing four main impacts that are distinct, but interrelated and interdependent:

- Increased technological unemployment in return for the creation and/or increase of more complex and skilled jobs;

- $\quad$ Need to develop new skills and abilities;

- Greater interaction between man and machine;

- $\quad$ Changes in socioprofessional relations.

Although there are doubts about job opportunities and jobs that will be extinguished, the fact is that there will be replacement of human labor by technology, whether by robotics or artificial intelligence, triggering the phenomenon of technological unemployment; consequently, there will be an increase in social inequality and reflections on the economy, politics and society itself, such as an increase in depression and violence. Therefore, it is time for governments to rethink their structures and develop regulatory and social policies to contingent the evils arising from technology.

It is already possible to draw an overview of the transformations in work relations, the reduction or even extinction of some professions, the creation of new jobs (Table 3). ${ }^{17}$

Some professions are more prone to automation, whose jobs will be reduced or even extinguished: telemarketing operators, people responsible for tax calculations, insurance appraisers, sports referees, legal secretaries, real estate brokers, agricultural workers, couriers and messengers.

Speed in development and technological innovation is exponential. According to Schwab, the world is multifaceted and deeply interconnected; new technologies generate even better and more technological products; the impact is systemic, entire systems will be transformed (among countries and within them, companies, industries, government and society); there is no time to wait, action is inevitable.

Artificial intelligence and robotics are gaining space and even conquering people, since they achieve more and more accurate results, with low probability of errors, in the short term, that is, the service improves and becomes faster.
In the medical area, it is already common to use robots in surgeries, screening care and diagnostics of some diseases. A study called What doctor? Why Al and robotics will define new health, conducted by Price Waterhouse Coopers, showed that most of the interviewees have no objections in receiving robot care (clarification of doubts, testing, diagnosis and treatment of diseases until small surgeries). About 11,000 people from 12 countries in Europe, Africa and the Middle East were interviewed, $55 \%$ of the participants said they were willing to be assisted by robots with artificial intelligence for faster access to health services (36\%), speed and accuracy of diagnoses (33\%), thus improving care and treatment; it was clear that confidence in technology is increasing. Lack of confidence in the robots' ability to make decisions (47\%) and lack of human contact (41\%) were cited by those who are not willing to undergo a robot-controlled treatment. ${ }^{18}$

It will be necessary to find a way to transform artificial intelligence into artificial assistants to help workers, train people, rethink professional training to meet this new reality. In addition to these aspects, other concerns have already arisen and have become daily accentuated. The use of artificial intelligence for illicit purposes such as scams (frauds), improper capture of personal data, attacks, cyber-attacks, fake news, industrial espionage, in short, the technology has brought benefits and criminals are also reinventing themselves with them.

The market will need qualified, competent professionals, not only capable of planning, executing and managing the new technologies, but also creative, proactive and innovative, and companies will need to provide new work environments with adequate structures, both in logistics and telecommunications.

Stakeholders in global society must come together to understand emerging trends, seeking solutions to problems arising from technological advances, among them, to update and develop survival mechanisms, because, as can be seen, disruptive technologies are available to various segments and business sectors that range from the operational area to strategic decision-making by company managers. Their use can optimize operations, reduce (or even avoid) expenses, eliminate error margins due to lack of information, reduce time in the production and execution of products and services, promoting faster processes, improving the purchasing experience and consumer satisfaction and, associated with all this, mass unemployment, the extinction of professions and the annihilation of companies that do not reinvent themselves based on this new reality and their perspectives.

\begin{tabular}{|c|c|c|}
\hline TRANSFORMATION & JOB REDUCTION & JOB CREATION \\
\hline Use of big data in quality inspection & Specialists in quality inspection & Industrial data analysts \\
\hline $\begin{array}{c}\text { Use of robots, autonomous vehicles } \\
\text { and 3D printers in production lines }\end{array}$ & $\begin{array}{c}\text { Production, assembly and } \\
\text { packaging operators } \\
\text { Logistics personnel }\end{array}$ & $\begin{array}{c}\text { Robot coordinators Engineers and } \\
\text { specialists in research and } \\
\text { development }\end{array}$ \\
\hline $\begin{array}{c}\text { Supply networks and autonomous } \\
\text { and intelligent production lines }\end{array}$ & Specialists in production planning & $\begin{array}{c}\text { Specialists in data modeling and } \\
\text { interpretation }\end{array}$ \\
\hline Automated predictive maintenance & Traditional maintenance technicians & Data, systems and IT analysts \\
\hline
\end{tabular}

Table 3 - Transformations versus jobs. Source: Adapted from Tessarini Junior and Saltorato. ${ }^{17}$ 


\section{H. Souza, A. C. Massabni}

\section{Conclusions}

The Fourth Industrial Revolution (or Revolution 4.0) began at the end of the 20th century, whose milestone is the interconnection of all stages of production, based on the digitalization of information, storage and use of data.

Artificial intelligence, high capacity for storing data and information and the speed of the internet, energy generation with lower levels of pollutants (clean or renewable energies), the use of nanotechnology, the emergence of virtual currencies, 3D printing, and augmented reality are examples of this revolutionary, new and highly technological era, which has promoted unprecedented changes in the economy, business, society and individuals, including their way of being, seeing and understanding the world. It is a total breakdown of paradigms, a historical phase that is just beginning.

The negative impacts of mass unemployment due to the replacement of human labor by highly technological machines cannot yet be estimated, which has been called disruptive technology, i.e., a product or innovative servant destabilizes competition, overcoming it in such a way that it promotes the rupture of existing models, ruining them. There are positive aspects such as technological advancement, comfort, ease and greater convenience for users (of society in general), but also harmful aspects, especially in work relations - all will be affected (companies, society and the governments). The world needs to reflect and prepare itself. The governments will lose revenue from tax collection; innovation in criminology with cybercrime and the use of Al for illicit practices; there will be an increase in poverty and in the amount of waste, due to the incentive to consumerism with the turnover of technological products launched and put on the market very quickly. Companies will need to adapt to this new reality, technological innovation is the watchword to maintain competitiveness.

Professionals will be needed to fill new jobs, with skills and competencies for Industry 4.0, whose interaction between man and machine is essential; use of big data in quality control, robots, fully automated vehicles, 3D printers in production lines, among other activities are examples of labor demands.

Undoubtedly, there are many challenges, but we must be prepared and overcome them, remodeling the industrial processes (production, consumption, transportation, logistics, among others) and work relations based on the demands of the technological revolution that has transformed humanity.

Revolution is synonymous of transformation and radical changes, but such changes and paradigm breakers should focus on the human beings and their well-being, safety and protection; everything that harms life, in its broadest concept (psychophysical integrity and dignity) should be seen sparingly. In this sense, the academic community must mobilize and assist the State in the adoption of policies capable of minimizing such impacts and ensuring work and dignity to the nation.

\section{References}

1. Schwab K. A Quarta Revolução Industrial. São Paulo: Edipro; 2016.

2. Penprase BE. The Fourth Industrial Revolution and higher education. In: Gleason NW (ed) Higher education in the era of the Fourth Industrial Revolution. Singapore: Palgrave Macmillan; 2018. https:// doi.org/10.1007/978-981-13-0194-0_9

3. Chris A. A Nova Revolução Industrial: Makers. Manhattan: Crown Publishing Group; 2012.

4. Tidd J. Digital disruptive innovation. Singapore: World Scientific Publishing Company; 2019. https://doi.org/10.1142/q0225

5. McPherson P, Talbot E. Disruptive technology. J Nurses Prof Dev. 2018;34(3):E1-3. https://doi.org/10.1097/ NND.0000000000000438

6. Dicio, Dicionário Online de Português. Disruptivo. 2019 [cited 2019
Sep 25]. Available from: https://www.dicio.com.br/disruptivo/

7. Santos PJT, Marco CM, Möller GS. Tecnologia disruptiva e direito disruptivo: compreensão do direito em um cenário de novas tecnologias. Rev Direito Práx. 2019;10(4):3056-91. https://doi. org/10.1590/2179-8966/2019/45696

8. Rasquilha L. Viagem ao futuro: a verdade sobre a prospectiva e o foresight. São Paulo: Actual; 2015.

9. Kelly K. What technology wants. United Kingdom: Penguin Books; 2011.

10. NASA Goddard Space Flight Center. Launch of Apollo 11 [Photograph]. 2008 [cited 2019 Sep. 25]. Available at: https://www.flickr. com/photos/gsfc/14483749397/

11. NASA's Marshall Space Flight Center. Archive: Apollo 11 Sees Earthrise (NASA, Marshall, 07/69) [Photograph]. 2012 [cited 2019 Oct. 2]. Available at: https://www.flickr.com/photos/nasamarshall/7974034982

12. U.S. Information Agency. Photograph of ENIAC (Electronic Numerical Integrator and Calculator) [Photograph]. 1900 [cited 2019 Oct. 15]. Available at: https://catalog.archives.gov/id/595506

13. Sandstein. IBM 5100 computer (1974), Swiss German keyboard and markings [Photograph]. 1974 [cited 2019 Oct. 2]. Available at: https://commons.wikimedia.org/wiki/File:IBM_5100___MfK_Bern. jpg

14. OLCF at ORNL. ORNL Launches Summit Supercomputer [Photograph]. 2018 [cited 2019 Oct. 15]. Available at: https://www.flickr. com/photos/olcf/27790972307

15. Lucas Junior HC, Goh JM. Disruptive technology: How Kodak missed the digital photography revolution. J Strategic Inf Syst. 2009;18(1):46-55. https://doi.org/10.1016/j.jsis.2009.01.002

16. Merrin S, Adler C. The power of positive destruction: how to turn a business idea into a revolution. Hoboken: John Wiley \& Sons; 2017.

17. Tessarini Junior G, Saltorato P. Impactos da Indústria 4.0 na organização do trabalho: uma revisão sistemática da literatura. Rev Prod Online. 2018;18(2):743-69. https://doi.org/10.14488/1676-1901. v18i2.2967

18. Arnold D, Wilson T. What doctor? Why Al and robotics will define New Health. PwC [Internet]. 2017 [cited 2019 Oct. 15]. Available at: https://www.pwc.com/gx/en/news-room/docs/what-doctor-whyai-and-robotics-will-define-new-health.pdf 